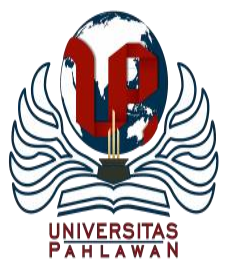

Edukatif : Jurnal Ilmu Pendidikan Volume 2 Nomor 1 April 2020 Halm 55-61

EDUKATIF: JURNAL ILMU PENDIDIKAN

Research \& Learning in Education

https:/ledukatif.org/index.php/edukatif/index

\title{
DAMPAK COVID-19 TERHADAP IMPLEMENTASI PEMBELAJARAN DARING DI SEKOLAH DASAR
}

\author{
Wahyu Aji Fatma Dewi ${ }^{1}$ \\ Universitas Kristen Satya Wacana ${ }^{1}$ \\ e-mail : wahyuajifatmadewi@gmail.com
}

\begin{abstract}
Abstrak
Penelitian ini bertujuan untuk mengidentifikasi implementasi pembelajaran daring dirumah pada siswa Sekolah Dasar akibat dari adanya pandemik COVID-19. Penelitian menggunakan penelitian kepustakaan dimana dalam mengumpulkan informasi data dengan teknik dokumentasi yaitu mencari data mengenai hal-hal yang relevan dari berbagai macam yang ada di perpustakaan seperti dokumen, buku, majalah, berita. Kriteria artikel dan berita yang dipilih yaitu adanya pembahasan tentang dampak COVID-19 dan pembelajaran daring di sekolah dasar. Dari 10 sumber yang didapatkan, kemudian dipilih yang paling relevan dan diperoleh 3 artikel dan 6 berita yang dipilih. Hasil dalam penelitian, menunjukkan bahwa dampak COVID-19 terhadap implementasi pembelajaran daring di sekolah dasar dapat terlaksanakan dengan cukup baik. Hal ini dapat dilihat dari hasil data 3 artikel dan 6 berita yang menunjukan bahwa dampak COVID-19 terhadap implementasi pembelajaran daring di SD dapat terlaksana dengan cukup baik apabila adanya kerjasama antara guru, siswa dan orang tua dalam belajar di rumah.
\end{abstract}

Kata Kunci: dampak Covid, pembelajaran daring.

\begin{abstract}
This study aims to identify the implementation of online learning at home in elementary school students due to the existence of the COVID-19 pandemic. The study uses library research where in collecting data information with documentation techniques that are looking for data about relevant things from various kinds in the library such as documents, books, magazines, news. The selected article and news criteria are discussion of the Impact of COVID-19 and Online Learning in Primary Schools. Of the 10 sources obtained, the most relevant were selected and 3 articles and 6 news were selected. The results of the study, showed that the impact of covid on the implementation of online learning in elementary schools could be implemented quite well. This can be seen from the results of data from 3 articles and 6 news that show that the impact of COVID-19 on the implementation of online learning in elementary schools can be done quite well if there is collaboration between teachers, students and parents in learning at home.
\end{abstract}

Keywords: impact of Covid-19, online learning.

@Edukatif: Jurnal Ilmu Pendidikan 2020

$\triangle$ Corresponding author :

Address : Semarang, Jawa Tengah, Indonesia

ISSN 2656-8063 (Media Cetak)

Email : wahyuajifatmadewi@gmail.com

ISSN 2656-8071 (Media Online)

Phone : 085600229624 


\section{PENDAHULUAN}

Di dunia saat ini sedang marak-maraknya wabah coronavirus. Coronavirus itu sendiri adalah keluarga besar virus yang menyebabkan penyakit mulai dari gejala ringan sampai berat. Ada setidaknya dua jenis corona virus yang diketahui menyebabkan penyakit yang dapat menimbulkan gejala berat. Coronavirus Diseases 2019 (COVID19) adalah penyakit jenis baru yang belum pernah diidentifikasi sebelumnya pada manusia. Tanda dan gelaja umum infeksi COVID-19 antara lain gejala gangguan pernapasan akut seperti demam, batuk, dan sesak napas. Masa inkubasi rata-rata 56 hari dengan masa inkubasi terpanjang 14 hari. Pada tanggal 30 Januari 2020 WHO telah menetapkan sebagai kedaruratan kesehatan masyarakat yang meresahkan dunia. Pada tanggal 2 Maret 2020, Indonesia melaporkan kasus konfirmasi COVID-19 sebanyak 2 kasus. Sampai dengan tanggal 16 Maret 2020 ada 10 orang yang dinyatakan positif corona. (Yurianto, Ahmad, Bambang Wibowo, 2020)

Dengan adanya virus COVID-19 di Indonesia saat ini berdampak bagi seluruh masyarakat. Menurut kompas, 28/03/2020 dampak virus COVID-19 terjadi diberbagai bidang seperti sosial, ekonomi, pariwisata dan pendidikan. Surat Edaran (SE) yang dikeluarkan pemerintah pada 18 Maret 2020 segala kegiatan didalam dan diluar ruangan di semua sektor sementara waktu ditunda demi mengurangi penyebaran corona terutama pada bidang pendidikan. Pada tanggal 24 maret 2020 Menteri Pendidikan dan Kebudayaan Republik Indonesia mengeluarkan Surat Edaran Nomor 4 Tahun 2020 Tentang Pelaksanaan Kebijakan Pendidikan Dalam Masa Darurat Penyebaran COVID, dalam Surat Edaran tersebut dijelaskan bahwa proses belajar dilaksanakan di rumah melalui pembelajaran daring/jarak jauh dilaksanakan untuk memberikan pengalaman belajar yang bermakna bagi siswa. Belajar di rumah dapat difokuskan pada pendidikan kecakapan hidup antara lain mengenai pandemi Covid-19.

Pembelajaran yang dilasanakan pada sekolah dasar juga menggunakan pembelajaran daring/jarak jauh dengan melalui bimbingan orang tua. Menurut Isman pembelajaran daring merupakan pemanfaatan jaringan internet dalam proses pembelajaran. Dengan pembelajaran daring siswa memiliki keleluasaan waktu belajar, dapat belajar kapanpun dan dimanapun. Siswa dapat berinteraksi dengan guru menggunakan beberapa aplikasi seperti classroom, video converence, telepon atau live chat, zoom maupun melalui whatsapp group. Pembelajaran ini merupakan inovasi pendidikan untuk menjawab tantangan akan ketersediaan sumber belajar yang variatif. Keberhasilan dari suatu model ataupun media pembelajaran tergantung dari karakteristik peserta didiknya. Sebagai mana yang diungkapkan oleh Nakayama bahwa dari semua literatur dalam $e$ learning mengindikasikan bahwa tidak semua peserta didik akan sukses dalam pembelajaran online. Ini dikarenakan faktor lingkungan belajar dan karakteristik peserta didik. (Nakayama M, Yamamoto H, 2007)

Tujuan dari penelitian ini adalah untuk mendapatkan informasi mengenai dampak COVID-19 terhadap implementasi pembelajaran daring di sekolah dasar. Apakah pembelajaran daring pada sekolah dasar bisa dilakukan dengan baik dan efektif. 


\section{METODE PENELITIAN}

Penelitian ini menggunakan penelitian kepustakaan. Penelitian kepustakaan merupakan suatu penelitian yang digunakan dalam mengumpulkan informasi dan data dengan bantuan berbagai macam material yang ada di perpustakaan seperti dokumen, buku, majalah, kisah-kisah sejarah, berita, dan sebagainya. Sedangkan menurut ahli penelitian kepustakaan merupakan kajian teoritis, referensi serta literatur ilmiah lainnya yang berkaitan dengan budaya, nilai dan norma yang berkembang pada situasi sosial yang diteliti (Sugiyono, 2012). Dalam penelitian ini, pengumpulan data diperoleh dari berita dan artikel-artikel pada jurnal online. Peneliti melakukan penelusuran artikel dengan menggunakan kata kunci “ Dampak Covid-19” dan "Pembelajaran Daring".

Berdasarkan penelusuran kata kunci "Dampak Covid" dan "Pembelajaran Daring" peneliti memperoleh berbagai macam berita dan artikel. Kriteria berita dan artikel yang dipilih yaitu adanya pembahasan tentang dampak Covid-19 dan pembelajaran daring. Dari 10 sumber yang didapatkan, kemudian dipilih yang paling relevan dan diperoleh 3 artikel dan 6 berita yang dipilih. Teknik penelitian yang dilakukan dengan dokumentasi, yaitu mencari data mengenai hal-hal atau variabel yang berupa catatan, buku, makalah atau artikel, jurnal dan berita. (Arikunto, 2010).

Dalam uji validitas peneliti menggunakan triangulasi sumber data. Analisis dilakukan dengan 4 tahap, antara lain 1) pengumpulan data; 2) reduksi data; 3) display data dan 4) Kesimpulan.

\section{HASIL DAN PEMBAHASAN}

Coronavirus adalah keluarga besar virus yang menyebabkan penyakit mulai dari gejala ringan sampai berat. Ada setidaknya dua jenis coronavirus yang diketahui menyebabkan penyakit yang dapat menimbulkan gejala berat seperti Middle East Respiratory Syndrome (MERS) dan Severe Acute Respiratory Syndrome (SARS). Coronavirus Diseases 2019 (COVID-19) adalah penyakit jenis baru yang belum pernah diidentifikasi sebelumnya pada manusia. Tanda dan gelaja umum infeksi COVID-19 antara lain gejala gangguan pernapasan akut seperti demam, batuk, dan sesak napas. Masa inkubasi rata-rata 56 hari dengan masa inkubasi terpanjang 14 hari. (Yurianto, Ahmad, 2020)

Penyebaran virus corona ini pada awalnya sangat berdampak pada dunia ekonomi yang mulai lesu, tetapi kini dampaknya dirasakan juga oleh dunia pendidikan. Kebijakan yang diambil oleh banyak negara termasuk Indonesia dengan meliburkan seluruh aktivitas pendidikan, membuat pemerintah dan lembaga terkait harus menghadirkan alternatif proses pendidikan bagi peserta didik maupun mahasiswa yang tidak bisa melaksanakan proses pendidikan pada lembaga pendidikan.

Aktivitas yang melibatkan kumpulan orang-orang kini mulai dibatasi seperti bersekolah, bekerja, beribadah dan lain sebagainya. Pemerintah sudah mengimbau untuk bekerja, belajar, dan beribadah dari rumah untuk menekan angka pasien yang terpapar COVID-19. Menteri Nadiem Anwar Makarim menerbitkan Surat Edaran Nomor 3 Tahun 2020 pada Satuan Pendidikan dan Nomor 36962/MPK.A/HK/2020 tentang Pelaksanaan Pendidikan dalam Masa 
Darurat Coronavirus Disease (COVID-19) maka kegaiatan belajar dilakukan secara daring (online) dalam rangka pencegahan penyebaran coronavirus disease (COVID0-19). (Menteri Pendidikan, 2020)

Dengan munculnya pandemik COVID-19 kegiatan belajar mengajar yang semula dilaksanakan di sekolah kini menjadi belajar di rumah melalui daring. Pembelajaran daring dilakukan dengan disesuaikan kemampuan masing-maisng sekolah. Belajar daring (online) dapat menggunakan teknologi digital seperti google classroom, rumah belajar, zoom, video converence, telepon atau live chat dan lainnya. Namun yang pasti harus dilakukan adalah pemberian tugas melalui pemantauan pendampingan oleh guru melalui whatsapp grup sehingga anak betul-betul belajar. Kemudian guruguru juga bekerja dari rumah dengan berkoordinasi dengan orang tua, bisa melalui video call maupun foto kegiatan belajar anak dirumah untuk memastikan adanya interaksi antara guru dengan orang tua.

Beberapa sekolah yang belum dapat menyelenggarakan KBM daring dapat mengembangkan kreativitas guru untuk memanfaatkan media belajar alternatif selama peserta didik belajar di rumah. Mereka dapat menggunakan sumber belajar yang ada yaitu buku siswa sesuai dengan tema-tema yang diajarkan sesuai jadwal yang telah dibuat sebelumnya.

Pembelajaran berbasis daring learning menunjukkan katerogisasi setuju. Hal ini ditunjukkan setelah mengikuti pembelajaran berbasis daring learning, para siswa semakin semangat mengikuti pembelajaran khusunya dalam pembelajaran IPA dan Para siswa tidak merasa bosan saat pembelajaran berlangsung. (Sobron et al., 2019)

Menurut Vicky dan Putri (Wicaksono \& Rachmadyanti, 2016) Penyelenggaran google classroom di sekolah dasar tanpa menyampingkan pembelajaran konvensional yang dilakukan. Hal ini merupakan kelebihan blended learning, dimana menggabungkan dua metode pembelajaran konvensional dan daring untuk membuat siswa merasa nyaman dan aktif dalam mengonstruksi pengetahuannya. Survei yang dilakukan Lenny N Rosalin Deputi Menteri PPPA Bidang Tumbuh Kembang Anak juga menunjukan harapan anak tentang program belajar dirumah. Anak-anak yang mengikuti survei dari 29 provinsi berharap agar sekolah tidak terlalu banyak memberikan tugas dan komunikasi dua arah antara guru dan murid dirasa lebih efektif. (Ade Nasihudin Al Ansori, 2020)

Menurut Heru Purnomo dalam pikiran rakyat media network pembelajaran jarak jauh dengan penerapan metode pemberian tugas secara daring bagi para siswa melalui whatsapp grup dipandang efektif dalam kondisi darurat karena adanya virus corona seperti sekarang ini. Banyak guru mengimplementasikan dengan cara-cara beragam belajar di rumah, dari perbedaan belajar itu basisnya tetap pembelajaran secara daring. Ada yang menggunakan konsep ceramah online, ada yang tetap mengajar di kelas seperti biasa tetapi divideokan kemudian dikirim ke aplikasi whatsapp siswa, ada juga yang memanfaatkan konten-konten gratis dari berbagai sumber. (Ashari, 2020)

Menurut Putra Wijaya dalam (Suryawan, 2020) belajar dirumah tidak menjadi masalah karena pembelajaran bisa dilakukan kapan dan dimana saja, apalagi sudah ada didukung dengan 
sistem daring. Jadi proses pembelajaran bisa terjadi di rumah, di sekolah maupun di masyarakat. Oleh karena itu semua bisa berjalan dengan baik, dengan dukungan fasilitas seperti internet.

Titik Kartikawati dalam guru SD Negeri

09 Sanggau, Kalimantan Barat mengatakan pembelajaran dirumah tetap dapat dilaksanakan. Ia mulai membuka kelas dari pukul 07.00 hingga 12.00. Dalam hal pelaksanaan belajar di rumah guru meminta bantuan orang tua atau kakak siswa sebagai narasumber yang langkah-langkahnya telah diberikan melalui grup whatsapp. Untuk laporan pelaksanaan pembelajaran dapat berupa foto atau video yang harus diposting melalui grup. Berbeda dengan Timur Setiawan menyampaikan beberapa metode pembelajaran secara daring yang telah diterapkan yaitu pembelajaran melalui portal rumah belajar dan penyampaian materi melalui file word yang dibagikan melalui media sosial whatsapp. (Pengelola Web Kemendikbud, 2020)

Pembelajaran daring saat ini dijadikan solusi dalam masa pandemic COVID-19. Tetapi pembelajaran daring tidak mudah seperti yang dibayangkan. Titi salah satu tenaga pendidik disalah satu sekolah dasar mengatakan dalam pembelajaran kelas 2 SD dia menggunakan zoom untuk meeting (pertemuan) tatap muka selayaknya di kelas. Tetapi tidak semua anak bisa akses karena ada yang orang tuaanya masih kerja, ada juga orang tua yang gagap teknologi. Selain itu titik juga mencari alternatif lain media pembelajaran daring dengan google doc, memberikan tautan yang berisi materi pelajaan sekaligus tugas serta batas waktu pengerkaan dinilai lebih bisa mengkomodir kebutuhan orang tua dan anak, ini dapat membantu penilai harian, nilai bisa langsung masuk berkas fom google. Lain halnya dengan Rita guru kelas 3 sekolah dasar. Di sekolah tempat Ritza bekerja, guru diwajibkan memberikan materi pelajaran dan tugas melalui alamat surat elektronik milik orang tua. Cara ini dinilai Ritza tak berjalan dengan efektif. Mengirimkan dokumen materi berupa power point, lalu anak mengerjakan dilaptop, dicetak atau tulis tangan lalu dikirim lewat whatsapp dinilai lebih efektif menurut Ritza. (Tim CNN Indonesia, 2020).

Menurut Agus, dkk dalam penelitiannya yang berjudul "Studi Eksploratif Dampak Pandemi COVID-19 Terhadap Proses Pembelajaran Online di Sekolah Dasar" dampak COVID-19 terhadap proses pembelajaran online di sekolah dasar berdampak terhadap siswa, orang tua dan guru itu sendiri. Beberapa dampak yang dirasakan murid yaitu murid belum ada budaya belajar jarak jauh karena selama ini sistem belajar dilaksanakan adalah melalui tatap muka, murid terbiasa berada di sekolah untuk berinteraksi dengan temantemannya, bermain dan bercanda gurau dengan teman-temannya serta bertatap muka dengan para gurunya, dengan adanya metode pembelajaran jarah jauh membuat para murid perlu waktu untuk beradaptasi dan mereka menghadapi perubahan baru yang secara tidak langsung akan mempengaruhi daya serap belajar mereka. Dampak terhadap orang tua yaitu kendala yang dihadapi para orang tua adalah adanya penambahan biaya pembelian kuota internet bertambah, teknologi online memerlukan koneksi jaringan ke internet dan kuota oleh karena itu tingkat penggunaaan kuota internet akan bertambah dan akan menambah beban pengeluaran orang tua. Dampak yang dirasakan guru yaitu tidak semua mahir menggunakan teknologi internet atau media sosial sebagai sarana pembelajaran, 
beberapa guru senior belum sepenuhnya mampu menggunakan perangkat atau fasilitas untuk penunjang kegiatan pembelajaran online dan perlu pendampingan dan pelatihan terlebih dahulu. Jadi, dukungan dan kerjasama orang tua demi keberhasilan pembelajaran sangat dibutuhkan. Komunikasi guru dan sekolah dengan orang tua harus terjalin dengan lancar.

\section{KESIMPULAN}

Berdasarkan hasil penelitian dan pembahasan di atas bahwa dampak COVID-19 terhadap implementasi pembelajaran daring di sekolah dasar dapat dilakukan dengan baik. COVID-19 begitu besar dampaknya bagi pendidikan untuk memutus rantai penularan pandemik COVID-19 pembelajaran yang biasanya dilakukan di sekolah sekarang menjadi belajar di rumah dengan menggunakan berbagai macam aplikasi seperti ruang guru, class room, zoom, google doc, google from, maupun melalui grup whatsapp. Kegiatan belajar dapat berjalan baik dan efektif sesuai dengan kreatifitas guru dalam memberikan materi dan soal latihan kepada siswa, dari soal-soal latihan yang dikerjakan oleh siswa dapat digunakan untuk nilai harian siswa.

Untuk anak sekolah dasar kelas I sampai III belum dapat mengoperasikan gawai maka dari itu dibutuhkannya kerjasama antara guru dengan orang tua, untuk orang tua yang bekerja sehingga tidak bisa mendampingi anak saat belajar dapat memerikan jadwal-jadwal belajar khusus agar bisa belajar seperti siswa yang lainnya. Jadi, adanya kerjasama dan timbal balik anatara guru, siswa dan orang tua yang menjadikan pembelajaran daring menjadi efektif.

\section{DAFTAR PUSTAKA}

Ade Nasihudin Al Ansori. (2020). Belajar di Rumah Akibat Corona COVID-19, Ini Pendapat dan Harapan Anak Indonesia. Liputan6.

https://m.liputan6.com/health/read/4224969/b elajar-di-rumah-akibat-corona-covid-19-inipendapat-dan-harapan-anak-indonesia

Arikunto, S. (2010). Prosedur Penelitian Suatu Pendekatan Praktik. Rineka Cipta.

Ashari, M. (2020). Proses Pembelajaran Daring di Tengah Antisipasi Penyebaran Virus Corona Dinilai Belum Maksimal. PikiranRakyatcom. https://www.pikiranrakyat.com/pendidikan/pr-01353818/prosespembejalaran-daring-di-tengah-antisipasipenyebaran-virus-corona-dinilai-belummaksimal

Menteri Pendidikan. (2020). Surat Edaran Nomor 3 Tahun 2020 Tentang Pelaksanaan Pendidikan dalam Masa Darurat CoronaVirus (COVID-19).

Nakayama M, Yamamoto H, \& S. R. (2007). The Impact of Learner Characterics on Learning Performance in Hybrid Courses among Japanese Students. Elektronic Journal ELearning, Vol.5(3).1.

Pengelola Web Kemendikbud. (2020). Kemendikbud Imbau Pendidik Hadirkan Belajar Menyenangkan Bagi Daerah yang Terapkan Belajar di Rumah. Www.Kemendikbud.Go.Id.

https://www.kemdikbud.go.id/main/blog/202 0/03/kemendikbud-imbau-pendidik-hadirkanbelajar-menyenangkan-bagi-daerah-yangterapkan-belajar-di-rumah

Sobron, A. ., Bayu, Rani, \& Meidawati. (2019). Persepsi Siswa Dalam Studi Pengaruh Daring Learning Terhadap Minat Belajar IPA. SCAFFOLDING: Jurnal Pendidikan Islam Dan Multikulturalisme.

Sugiyono. (2012). Metode Penelitian Kuantitatif Kualitatif dan $R \& D$. Alfabeta.

Suryawan, O. (2020). Guru Diminta Aktif Awasi Pembelajaran Daring Agar Siswa Tetap 
61 Dampak Covid-19 terhadap Implementasi Pembelajaran Daring di Sekolah Dasar - Wahyu Aji Fatma Dewi

Fokus. BBALIPUSPANEWS.COM.

Tim, C. I. (2020). Corona, Kelas Daring, dan Curhat 2 Guru untuk Orang Tua. CNN Indonesia. https://m.cnnindonesia.com/gayahidup/20200330165053-284-488368/coronakelas-daring-dan-curhat-2-guru-untuk-orangtua

Wicaksono, V. D., \& Rachmadyanti, P. (2016). Pembelajaran Blended Learning melalui Google Classroom di Sekolah Dasar. Seminar Nasional Pendidikan PGSD UMS \& HDPGSDI Wilayah Timur.

Yurianto, Ahmad, Bambang Wibowo, K. P. (2020). PEDOMAN PENCEGAHAN DAN PENGENDALIAN CORONAVIRUS DISEASE (COVID-19) (M. I. Listiana Azizah, Adistikah Aqmarina (ed.)). 